\title{
Introducing urban food forestry: a multifunctional approach to increase food security and provide ecosystem services
}

\author{
Kyle H. Clark $\cdot$ Kimberly A. Nicholas
}

Received: 7 May 2012/ Accepted: 4 June 2013/Published online: 16 July 2013

(C) The Author(s) 2013. This article is published with open access at Springerlink.com

\begin{abstract}
We examine the potential role of perennial woody food-producing species ("food trees") in cities in the context of urban sustainable development and propose a multifunctional approach that combines elements of urban agriculture, urban forestry, and agroforestry into what we call "urban food forestry" (UFF). We used four approaches at different scales to gauge the potential of UFF to enhance urban sustainability and contribute to food security in the context of urbanization and climate change. First, we identified 37 current initiatives based around urban food trees, and analyzed their activities in three categories: planting, mapping, and harvesting, finding that the majority (73\%) only performed one activity, and only $8 \%$ performed all three. Second, we analyzed 30 urban forestry master plans, finding that only $13 \%$ included human food security among their objectives, while $77 \%$ included habitat for wildlife. Third, we used Burlington, Vermont as a case study to quantify the potential fruit yield of publicly accessible open space if planted with Malus domestica (the common apple) under nine different planting and yield scenarios. We found that $108 \%$ of the daily recommended minimum intake of fruit for the entire city's population could be met under the most ambitious planting
\end{abstract}

K. H. Clark · K. A. Nicholas $(\bowtie)$

Lund University Centre for Sustainability Studies

(LUCSUS), Box 170, 22100 Lund, Sweden

e-mail: kimberly.nicholas.academic@gmail.com scenario, with substantial potential to contribute to food security even under more modest scenarios. Finally, we developed a Climate-Food-Species Matrix of potential food trees appropriate for temperate urban environments as a decision-making tool. We identified a total of 70 species, 30 of which we deemed "highly suitable" for urban food forestry based on their cold hardiness, drought tolerance, and edibility. We conclude that substantial untapped potential exists for urban food forestry to contribute to urban sustainability via increased food security and landscape multifunctionality.

Keywords Urban agriculture - Urban forestry · Sustainability science $\cdot$ Edible landscaping . Agroforestry · Agroecology

\section{Introduction}

Urbanization and sustainability

Rapid worldwide urbanization has reshaped civilization over the past century, as the percentage of people living in cities has risen from roughly 10 to over $50 \%$ (Grimm et al. 2008). Urbanization will continue to shape the future, as essentially all new population growth is projected to take place in urban areas, and over $60 \%$ of the total population is expected to reside 
in cities by 2030 (United Nations 2004). Aside from the many conveniences they offer, cities have become concentrated areas of production and consumption, radically altering global biophysical, economic, and social systems. Sustaining the well-being of urban populations requires a constant and growing stream of natural resources imported from rural areas, as well as the natural areas required to process the waste that cities generate. Ecological footprint analyses document that this may require non-urban land hundreds of times larger than the area of the city itself (Rees 1992; Rees and Wackernagel 1996).

As we face an increasingly urbanized future, urban sustainability, or "the dynamic capacity of an urban area for adequately meeting the needs of its present and future populations through ecologically, economically, and socially sound planning, design, and management activities" (Wu 2008) is an increasingly urgent topic in academic, planning, and policy circles. Identifying sustainable urbanization strategies is widely acknowledged as key to global sustainable development (Camhis 2006; Clark 2007; FAO 2008). This will require incorporating elements of sustainability science, including focusing on place-based, solution-driven research; making use of adaptive management and social learning; and using interdisciplinary research approaches, and transdisciplinary coordination to both understand and implement such strategies (Kates et al. 2001; Wu 2008).

\section{Landscape ecology theory and sustainable cities}

Over the last several decades, urban landscapes have become an increasing focus of ecological study (Grimm et al. 2008). In particular, the potential for landscape ecology to contribute both to theories of sustainable urban development, and to landscape design and practice to achieve sustainability outcomes, has been highlighted (Breust et al. 2008; Wu 2008; Lovell and Johnston 2009; Wu 2010; Musacchio 2011). However, bridging knowledge and application has proved difficult in practice (Potschin and HainesYoung 2006; Wu 2006; Nassaur and Opdam 2008; Musacchio 2011). Emphasizing design as a common ground for scientists and practitioners to collaborate could be used to bridge this gap (Nassaur and Opdam 2008; Lovell and Johnston 2009; Termorshuizen and Opdam 2009; Musacchio 2011).
Maximizing landscape contributions to sustainable development can be promoted through multifunctionality, i.e., designing landscapes to simultaneously and efficiently integrate multiple ecosystem services (Lovell and Johnson 2009; Termorshuizen and Opdam 2009; Lovell 2010; O'Farrell and Anderson 2010; Ahern 2012). For example, incorporating a bioswale in a public space could provide the regulating services of storm water retention and bioremediation, the biotic services of wildlife habitat, and the cultural services of educational opportunities and aesthetic character. Structurally integrating ecosystem services into landscape planning, management, and design is critical to improving urban landscape sustainability and resilience, and improving human well-being (de Groot et al. 2009; Lovell and Johnston 2009; Lundy and Wade 2011). Finally, recent literature highlights that the research agendas of landscape ecology and sustainability science (see Clark 2007) are complimentary for achieving sustainability outcomes, and can be used in conjunction to quantify landscape sustainability and performance (Wu 2006; Wu 2008; Termorshuizen and Opdam 2009; Musacchio 2011).

Food security

Maintaining the food security of rapidly growing urban populations, particularly the poor, will be one of the greatest challenges of the 21st century (Camhis 2006; Clark 2007; Easterling 2007; Tanumihardjo et al. 2007; FAO 2008; Godfray et al. 2010). Challenges to food security, the condition "when all people, at all times, have physical and economic access to sufficient safe and nutritious food that meets their dietary needs and food preferences for an active and healthy life" (FAO 2008), could be greatly exacerbated by climate change, geopolitical insecurity, energy supply disruptions, transport failures, and a variety of other unpredictable supply shocks (Fraser et al. 2005; Schmidhuber and Tubiello 2007; FAO 2008; Cluff and Jones 2011). The interaction of poverty and ecosystem services such as food provision has been suggested as a grand challenge topic in landscape ecology, to align with efforts by governments and scientists in other disciplines to address millennium development goals (Pijanowski et al. 2010).

Malnutrition is a major component of food security that is expressed not only through undernutrition and 
hunger, but also overnutrition and obesity, both of which are rapidly growing global epidemics closely linked to poverty (Darmon et al. 2005; Tanumihardjo et al. 2007). This is due in part to higher costs of nutrient-dense foods like fruits and vegetables, and the wide availability of low-cost, energy-dense foods from industrial agriculture (Schmidhuber and Shetty 2003; Darmon et al. 2005). Non-communicable diseases linked with malnutrition and obesity (e.g., cardiovascular disease, cancer, and diabetes) are expected to surpass undernutrition as the leading cause of death in low-income communities by 2015 (Tanumihardjo et al. 2007).

Urban agriculture, urban forestry, and agroforestry

Urban agriculture is among the most prominent strategies in both developed and developing contexts to improve food security and nutritional status. In 1996, the United Nations Development Program estimated that 800 million people are engaged in urban and peri-urban agriculture worldwide, a quarter of whom are market producers, employing 150 million people full-time and producing $15 \%$ of the world's food (FAO/WB 2008). Numerous modern cities contain extensive urban agriculture systems, including Shanghai, China, where $60 \%$ of the vegetables and $90 \%$ of the eggs consumed by residents are produced within the city (Bhatt and Farah 2009), and Amsterdam, which contains over 350 hectares of land devoted to urban gardens (van Leeuwen et al. 2010). Urban agriculture has been shown repeatedly to contribute to food security through providing nutrient-dense food directly, as well as income from produce sales and employment (e.g., FAO 2008; Dubbeling et al. 2009; Zezza and Tasciotti 2010; De Zeeuw et al. 2011). Historical cases such as "victory gardens" in the 1940s in the United States, and more recently in Cuba, provide examples of the resilience that urban agriculture offers in the face of extreme shocks to urban food and energy supplies (Altieri et al. 1999; Lovell 2010). For these reasons, urban agriculture is promoted as a resilience-enhancing strategy by the FAO, World Bank, European Union, World Meteorological Organization, World Health Organization (WHO), and U.S. Department of Agriculture (USDA) (FAO/WHO 2004; Dubbeling et al. 2009; De Zeeuw et al. 2011).

Like urban agriculture, urban forestry provides a diverse set of social, ecological and economic services in cities worldwide (see Konijnendijk and Gauthier 2006), which contain millions of hectares of urban forest (Konijnendijk 2003). Urban forestry emerged in North America in the 1960s as an innovative strategy to manage urban natural resources (Konijnendijk and Gauthier 2006), and has since evolved to assess the structure, function, and value of urban trees (e.g., Maco and McPherson 2003; Nowak 2006) and apply concepts from forest ecology and ecosystem management to the urban forest (Rowntree 1998; Nowak and Dwyer 2007). It is now commonplace for major cities to formulate urban forestry master plans to establish tree selection criteria, calculate total urban canopy coverage, and provide long-term goals such as reducing the urban heat island effect, managing storm water run-off, and increasing property value (Konijnendijk 2003; Nowak and Dwyer 2007).

Although urban forestry is increasingly common, practicing agroforestry, the cultivation of woody perennial plants in conjunction with crop or animal farming, has been primarily restricted to rural settings and is rarely practiced in cities. Agroforestry combines the functions of annual crop agriculture and woody perennial cultivation and is recognized as a timehonored agroecological practice for addressing multiple sustainability and community resilience challenges (Nair 1993; Kumar 2006; Nair 2007). Agroforests have been planted since ancient times in both tropical and temperate climates to serve multiple purposes (Smith 1929; Lelle and Gold 1994; Sachez 1995), and have gained increased attention by governments and development organizations for their ability to alleviate poverty and food insecurity (Garrity 2004) while providing a wide variety of ecosystem services such as soil regeneration and biodiversity habitat (Belsky 1993; Nair 1993; Kumar 2006; Blanco and Lal 2010). Agroforestry is economically efficient and can reduce production costs by lowering needs for inputs such as water, chemicals, and labor, while increasing agricultural output (Lassoie and Buck 2000; Olson et al. 2000; Bentrup and Kellerman 2003; Lal 2012).

Introducing and examining urban food forestry

Despite their functional similarities and ubiquity throughout urban landscapes, urban agriculture and urban forestry have remained relatively separate in their science and practice, and neither practice has integrated ecological design concepts from agroforestry. In this 
paper, we propose integrating elements of urban agriculture, urban forestry, and agroforestry to develop a novel, multifunctional approach to improve urban landscape sustainability, which we term urban food forestry (UFF). We define urban food forestry as "the intentional and strategic use of woody perennial foodproducing species in urban edible landscapes to improve the sustainability and resilience of urban communities." The emphasis on perennial woody fruitand nut-producing species (food trees) distinguishes UFF from conventional forms of both urban agriculture and urban forestry.

Urban food forestry can more efficiently integrate ecosystem services into landscapes and minimize trade-offs through the strategic use and combination of multifunctional species that embody services of both urban forestry, such as air quality, water and climate regulation, oxygen production, erosion control, and biodiversity habitat (Konijnendijk 2003; Nowak 2006; Nowak and Dwyer 2007), and urban agriculture, including increasing community food security, public health, social capital, and microenterprise opportunities (Brown and Jameton 2000; FAO/WHO 2004; Dubbeling et al. 2009; Lovell 2010; De Zeeuw et al. 2011), while also integrating agroecological design practices of agroforestry to further enhance ecosystem service provision. Urban food trees also offer unique possibilities for cultural and recreational services through public edible landscapes that provides food as a common-pool public produce resource (Nordahl 2009), and for practical knowledge innovation by bridging gaps between urban planning and various agronomic and horticultural sciences.

Given the absence of research on this topic, we sought to investigate the initial feasibility and prevalence of UFF within a temperate developed context using four complimentary research approaches at different scales. First, we identified existing initiatives with English-language websites that fit our definition of UFF, and classified their activities into three categories of planting, mapping, and harvesting. Second, we examined the prevalence of food security as an objective within municipal urban forestry planning by analyzing 37 North American urban forestry master plans. Third, we developed a local case study of the production potential of UFF using geographic information system (GIS) analysis to determine how much publicly accessible open space is available in the city of Burlington, Vermont; we then used horticultural data to calculate the potential agronomic yield of this land if it were planted with Malus domestica (the common apple) under nine potential scenarios of varying planting coverage and yields. Fourth, we developed a ClimateFood-Species Matrix (CFSM) of 70 perennial foodproducing species suitable for urban environments, using the work of Roloff et al. (2009) as our starting point, and ranked each species in terms of edibility, drought tolerance, and cold hardiness. We conclude by discussing design and implementation considerations, and considering our findings within the greater context of urban sustainability and resilience, particularly with regard to food security.

Our overall objectives are, first, to introduce urban food forestry as one strategy for improving urban food security through the provision of affordable or free nutrient-dense produce, while simultaneously improving the multifunctionality of urban agriculture (e.g., increasing biodiversity habitat and carbon sequestration capacity). Second, we aim to provide a common ground for knowledge transfer between urban agriculture, urban forestry, agroforestry, and other relevant disciplines, and link this knowledge with practice.

\section{Methods}

Urban food forestry initiatives

We searched for and documented existing initiatives currently planting or using food trees in urban environments. We identified initiatives through iterative online searches using terms such as "community orchard," "urban orchard," "urban fruit trees," "city fruit trees," "city fruit map," "urban food forest," "public orchard," "edible park," and "fruit tree project." We then examined the mission statements and reported activities of these initiatives and recorded whether they were engaged in planting, mapping, or harvesting urban food trees, or some combination thereof.

Urban forestry master plan analysis

We identified urban forestry master plans (UFMPs) through online searches using the phrase "urban forestry master plan." We downloaded all available resulting UFMPs and analyzed their content to determine the prevalence of food production as a species 
selection and planning criterion. We searched for the phrases "fruit," "food," and "wildlife," and recorded instances in which these words were used in the context of human food security and wildlife habitat, including providing food for wildlife.

The potential urban food forestry capacity of Burlington, VT

\section{Available urban public land}

We assembled publicly available GIS data for the city of Burlington, Vermont (USA) from the Vermont Center for Geographical Information (http:// www.vcgi.org) and the City of Burlington (http:// www.ci.burlington.vt.us/gis/), including layers for town boundaries, property parcels, public lands, parks, and bicycle paths. We extracted publicly owned open space parcels from the Burlington parcel layer and crosschecked these parcels with aerial photos. We used ArcGIS to calculate the total area of publicly accessible open space, excluding sidewalk strips as these sites may be unsuitable for public food trees due to falling fruit. We also excluded other potentially plantable areas including parcels associated with public schools, universities, churches, private companies, cemeteries, and right-of-ways.

\section{Calculating productive capacity of planted land}

We calculated the production capacity of open space planted with apple trees, which were chosen for their local suitability and the availability of agronomic data. Note that we are not suggesting that monocultures of apples should be planted in edible landscapes; they are meant to be illustrative in this case. To span the range of uncertainty in program implementation and to account for potentially wide variations in fruit yield, we calculated apple production for a factorial combination of three levels of two factors: (1) the amount of available open space planted with apple trees, either 5, 25 , or $50 \%$; and (2) low, medium, and high yields per hectare planted (based on achieving 25, 50, and $75 \%$ of optimal yields, respectively), for a total of nine planting scenarios.

The amount of open space planted with trees would depend on the level of program investment and local site suitability, but is straightforward to calculate. Estimating yield, however, is more complicated, because it depends on a variety of site-specific factors, including soil quality, climate, rootstock, cultivar, shade, and management, as well as annual fluctuations. These characteristics also interact with planting density; high-density orchards planted with more trees per hectare tend to lead to smaller trees that produce small apples, while lower-density orchards of fewer trees per hectare tend to lead to larger trees producing more, larger apples (Weber 2000; Robinson et al. 2007). However, these opposing trends result in similar yields per hectare. Recent work analyzing research trials in New York State with apple trees planted at densities varying by more than sixfold, between 840 and 5,380 trees/ha, has shown remarkably consistent optimal yields within $10 \%$ of 1,000 bushels per acre (53.8 tons/ha) (Robinson et al. 2007). Therefore, we used this value as an upper limit on potential yields, and adjusted it downward to 25, 50, and $75 \%$ of this level $(13.5,26.9$, and 40.4 tons/ha, respectively) to account for the variety of conditions in Burlington's open spaces, which range from prime agricultural soil to compacted fill or semi-shaded areas. These estimates seem reasonable given that yields of over $86 \mathrm{Mt} /$ ha have been recorded in recent orchard trials in the Champlain Valley, where Burlington is located (NNYADP 2010). We estimated the total edible quantity of apples produced under each scenario by multiplying the number of hectares planted with the expected yield per hectare; this total mass of fruit produced was converted to edible mass by assuming that $90 \%$ of gross apple yields were edible (Stewart et al. 2011), and converted to calories assuming that each gram of apple contains 0.54 kilocalories (USDA 2009).

Although the optimal level of yields per hectare could be achieved with various planting densities, recent work has shown several advantages of highdensity orchards, particularly in this region where the optimal density was found to be between 2,470 and 2,964 trees per hectare (Robinson et al. 2007; NNYADP 2010; Bradshaw et al. 2012); therefore, we have used a density of 2,400 trees per hectare in translating our planting scenarios based on hectares to trees, although as we note above, the same levels of yields could be achieved at a variety of planting densities. Modern high-density orchards featuring trees planted at $1 \mathrm{~m}$ spacing or less are sometimes referred to as "fruiting walls" owing to their twodimensional appearance; this configuration still leaves 
up to $76 \%$ of each planted hectare as open grass available for recreational or other uses (Robinson 2005). Major advantages of planting in this fashion are much shorter trees (2-3 m high) with more accessible fruit and lower maintenance requirements, which achieve substantial yields within the first two to four years, and full production by year five (Robinson et al. 2007). Lower-density plantings that result in fewer, larger trees can achieve require up to twice as much time to achieve similar yields per hectare (North Carolina Cooperative Extension Service (NCCE) 2008; Robinson 2011). However, high-density plantings require trellising for tree support (Robinson 2005, Robinson et al. 2007; NCCE 2008).

In terms of management, we assumed that communities would select high-yielding, disease- and pestresistant cultivars, and that they would use standard organic and agroecological management practices, along with minimal applications of organic sprays as needed or desired to improve fruit quality. We are only aware of one study that compares the yield performance of organic (including approved insecticides and fungicides) with conventional apple orchards, which concluded over a five-year period that organic orchards can achieve yields comparable to conventional orchards while producing sweeter, less tart apples and higher soil quality (Reganold et al. 2001). Other studies have found that increasing beneficial insects by planting perennial flowers in apple orchards can dramatically reduce the need for insecticides (Bostonian et al. 2004), and that apples receiving no fungicide spray applications can achieve yields comparable to those under conventional management (Ellis 1998), albeit with superficial blemishes that do not affect food safety (McManus and Heimann 1997).

\section{People fed by urban food forestry}

We estimated the number of people that could benefit from eating apples produced by our planting scenarios in two ways. First, we estimated the number of very food-insecure (VFI) people in Burlington. Since food security data was not available for the city of Burlington, we used the statewide average for Vermont, where $6.1 \%$ of households are classified as having very low food security (compared with $5.6 \%$ nationally). This condition is defined as households where "at times during the year, the food intake of household members was reduced and their normal eating patterns were disrupted because the household lacked money and other resources for food" (USDA 2011:5). While the average number of people per household is comparable between Burlington (2.15) and Vermont (2.34), the poverty rate is 2.2 times higher in Burlington (25\% of people below the poverty line) than in the rest of the state $(11.3 \%$ below the poverty line) (United States Census Bureau 2011). Since household-level food security data were not available for Burlington, we used poverty level as a proxy and multiplied the statewide VFI rate by 2.2 to estimate the number of VFI households in Burlington.

We calculated the percentage of the VFI population meeting the definition above that could have their caloric deficit met by apples produced from publicly accessible open space by comparing the edible calories produced under our nine planting and yield scenarios to the total caloric deficit of VFI individuals. While we are not suggesting that consuming only apples would provide an adequate strategy for very food insecure individuals, this estimate establishes the order of magnitude of food that an urban forestry program could provide, relative to a measure of community food need currently not being met. We used the following formula to calculate the caloric deficit:

Total annual caloric deficit in Burlington

$$
=\mathrm{H} \times \mathrm{VFI} \times \mathrm{P} \times \mathrm{I} \times \mathrm{CD} \times 365 \text { days }
$$

where $\mathrm{H}$ is the households in Burlington (16,773, according to the United States Census Bureau 2011), VFI is the percentage of Vermont households with very low food security (6.1\%, USDA 2011), P is the poverty rate in Burlington relative to statewide Vermont poverty rate, to adjust VFI (2.2, United States Census Bureau 2011), I is the individuals per household in Burlington (2.15, US Census Bureau United States Census Bureau 2011), CD is the estimated percent daily caloric deficit for a VFI individual (our conservative estimate of $25 \%$, roughly equivalent to skipping breakfast daily; this is approximately five times higher than the FAO (2010) estimated food deficit of undernourished individuals of $100 \mathrm{kcal} / \mathrm{day}$ ), and $\mathrm{CR}$ is the average minimum daily caloric requirement for an average adult $(2,000 \mathrm{kcal} / \mathrm{day}$, USDA 2011). 
We also calculated the number of people whose minimum recommended intake of fruit (200 grams/day) could be met by our 9 planting scenarios by dividing the edible fruit production by the annual fruit recommendation for an individual $(73 \mathrm{~kg} /$ year). Recommended fruit intake was derived from a joint report by the FAO and WHO, which recommends a minimum of $400 \mathrm{~g}$ of fruit and vegetables per day (FAO/WHO 2004). Since the percentage of vegetables and fruits that make up this $400 \mathrm{~g}$ is not specified, we assumed that it should be equally divided between fruits and vegetables. Note that these calculations were again performed for clarity and we are not suggesting that the fruit consumption for Burlington consist exclusively of apples, or that the entire yield of urban food forestry systems would consist of apples; we envision UFF in practice producing a wide diversity of locally-selected fruits and nuts, as represented by the CFSM. Importantly, however, epidemiological studies have linked the consumption of apples with reduced risk of some cancers, cardiovascular disease, asthma, and diabetes (Boyer and Liu 2004; Gerhauser 2008), making them a particularly strong choice for improving community food security.

\section{Climate-Food-Species Matrix}

We created a reference table of perennial foodproducing plants, the CFSM, starting with the 250 commonly planted urban tree species included in the Climate-Species Matrix developed by Roloff et al. (2009), which assessed tree cold hardiness and drought tolerance. We added other perennial foodproducing species, including shrubs and vines, to this list using horticultural reference databases and extension publications, which were also used to assess their commercial cultivation status and cold and drought tolerance (Plants for a Future 2010; USDA ARS 2010; Purdue University New Crop Resource Online Program 2011). Unlike Roloff et al. (2009), we used degrees Celsius as our metric of hardiness and either 'Yes' or 'No' for drought tolerance, designating species ranked by Roloff et al. (2009) as either 'suitable' or 'very suitable' to be drought tolerant. We also included plant heights to aid in multi-story design, as is common in agroforestry, though a full discussion of companion planting and food forest design is beyond our scope (see Jacke and Toensmeier 2005; Crawford 2010).
Each plant was assessed for edibility based on five criteria: (1) fit for human consumption, (2) commercial cultivation and breeding for human food, (3) wide recognition and marketing, (4) fruit or nut palatability when eaten raw, and (5) edibility without special preparation (e.g., peeling or cooking), with one point given for each criteria met. The edibility scale therefore ranged from 1 (theoretically edible) to a maximum value of 5 (highly edible).

\section{Results}

Urban food forestry initiatives

Our search identified 37 initiatives currently engaged in what we describe as urban food forestry (Table 1). An analysis of the mission statements and activity descriptions found on their websites revealed that these projects engaged in a combination of one or more of three activities: planting, mapping, and harvesting produce from urban food trees (Fig. 1).

Planting initiatives were often described as collaborations between municipalities and community members to establish food trees on open space within city limits. These initiatives stated a wide range of goals including enhancing local food security, public education, community revitalization, carbon sequestration, erosion control, air quality improvement, poverty reduction, crime reduction, beautification, noise pollution reduction, microclimate control, shade provision, entrepreneurship, preservation of rare plant genetics, and building social capital. Food security was the most commonly cited objective. Two planting initiatives (Fruit Tree Planting Foundation and Communities Take Root) operate as charities on a nationwide basis and plant numerous community urban orchards each year.

Mapping initiatives utilized hand-drawn maps (e.g., Fallen Fruit) or Internet-based participatory maps that allow anyone to add to trees to the map. One of the larger participatory mapping initiatives is Neighborhood Fruit, whose users have mapped over 10,000 publicly accessible fruit trees in North America as of February 2012. These trees can be searched on their website or via smart phone applications.

Harvesting initiatives focused on making use of produce from underutilized urban food trees on both 
Table 1 Thirty-seven community initiatives based around urban food trees, and the activities in which they are engaged, identified from an iterative online search. Nearly three-quarters of initiatives were founded in 2007 or later, and the same number engage in only one of the three activities

\begin{tabular}{|c|c|c|c|c|c|}
\hline Name of initiative or organization & Location & Founded & Planting & Mapping & Harvesting \\
\hline City Fruit & Seattle, WA & 2008 & $\mathrm{x}$ & $\mathrm{x}$ & $\mathrm{x}$ \\
\hline Fallen Fruit & Los Angeles, CA & 2004 & $\mathrm{x}$ & $\mathrm{x}$ & $\mathrm{x}$ \\
\hline Life Cycles Fruit Tree Project & Victoria, BC & 2000 & $\mathrm{x}$ & $\mathrm{x}$ & $\mathrm{x}$ \\
\hline Madison Fruits and Nuts & Madison, WI & 2010 & $\mathrm{x}$ & $\mathrm{x}$ & \\
\hline City of Calgary Community Orchards & Calgary, Canada & 2009 & $\mathrm{x}$ & $\mathrm{x}$ & \\
\hline Ben Nobleman Community Orchard & Toronto, Canada & 2009 & $\mathrm{x}$ & $\mathrm{x}$ & \\
\hline Philadelphia Orchard Project & Philadelphia, PA & 2007 & $\mathrm{x}$ & $\mathrm{x}$ & \\
\hline San Francisco Urban Orchards Project & San Francisco, CA & 2012 & $\mathrm{x}$ & & $\mathrm{x}$ \\
\hline Urban Abundance Fruit Tree Program & Vancouver, BC & 2009 & $\mathrm{x}$ & & $\mathrm{x}$ \\
\hline Beacon Food Forest & Seattle, WA & 2011 & $\mathrm{x}$ & & \\
\hline Union Street Urban Orchard & London, UK & 2010 & $\mathrm{x}$ & & \\
\hline Bloomington Community Orchard & Bloomington, IN & 2010 & $\mathrm{x}$ & & \\
\hline Communities Take Root & $30+$ cities, USA & 2010 & $\mathrm{x}$ & & \\
\hline Rapid City Urban Orchard Project & Rapid City, SD & 2010 & $\mathrm{x}$ & & \\
\hline Chicago Rarities & Chicago, IL & 2009 & $\mathrm{x}$ & & \\
\hline Husthwaite Community Orchard & Husthwaite, UK & 2009 & $\mathrm{x}$ & & \\
\hline London Orchard Project & London, UK & 2009 & $\mathrm{x}$ & & \\
\hline Fruit Tree Planting Foundation & $100+$ cities & 2002 & $\mathrm{x}$ & & \\
\hline Dr. G.W. Carver Edible Park & Asheville, NC & 1998 & $\mathrm{x}$ & & \\
\hline Community Harvest of SW Seattle & Seattle, WA & 2007 & & $\mathrm{x}$ & $\mathrm{x}$ \\
\hline Boskoi Urban Edibles & Netherlands & 2010 & & $\mathrm{x}$ & \\
\hline Neighborhood Fruits & USA, Canada & 2009 & & $\mathrm{x}$ & \\
\hline Hackney Harvest & London, UK & 2009 & & $\mathrm{x}$ & \\
\hline Urban Edibles & Portland, OR & 2006 & & $\mathrm{x}$ & \\
\hline Pierce County Gleaning Project & Tacoma, WA & 2010 & & & $\mathrm{x}$ \\
\hline Food Forward & S. California & 2009 & & & $\mathrm{x}$ \\
\hline Neighborhood Fruit Harvest & Ashland, OR & 2008 & & & $\mathrm{x}$ \\
\hline Not Far From the Tree & Toronto, Canada & 2008 & & & $\mathrm{x}$ \\
\hline North Berkeley Harvest & Berkeley, CA & 2008 & & & $\mathrm{x}$ \\
\hline Abundance Manchester & Manchester, UK & 2008 & & & $\mathrm{x}$ \\
\hline Grow Sheffield & Sheffield, UK & 2007 & & & $\mathrm{x}$ \\
\hline Solid Ground Fruit Tree Harvest & Seattle, WA & 2007 & & & $\mathrm{x}$ \\
\hline Backyard Harvest Community Orchard & Moscow, ID & 2006 & & & $\mathrm{x}$ \\
\hline Portland Fruit Tree Project & Portland, OR & 2006 & & & $\mathrm{x}$ \\
\hline Boston Area Gleaners & Boston, MA & 2004 & & & $\mathrm{x}$ \\
\hline Village Harvest & S. California & 2001 & & & $\mathrm{x}$ \\
\hline Vancouver Fruit Tree Project Society & Vancouver, BC & 1999 & & & $\mathrm{x}$ \\
\hline Total & & & 19 & 12 & 19 \\
\hline
\end{tabular}

public ("urban gleaning") and private ("backyard harvesting") land. Some organizations (e.g., Not Far From the Tree) allow private food tree owners to register food trees on their website; volunteers are then sent to harvest fruit, and the resulting harvest is typically divided between the tree owner, volunteers, and food banks. There was some evidence of cooperation between harvesting and planting initiatives, and at least 


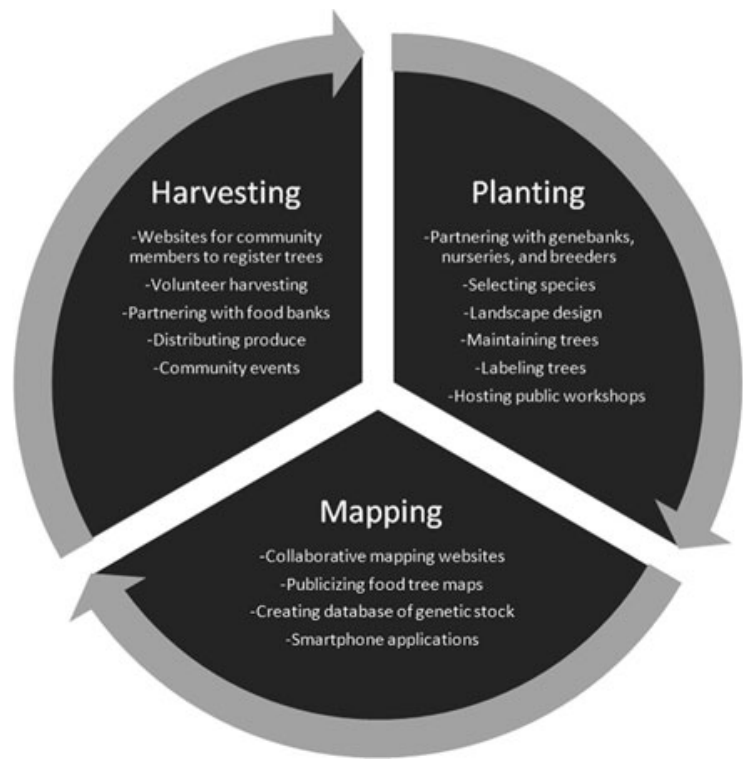

Fig. 1 Urban food forestry initiatives can be divided into three distinct elements, or pillars: planting, mapping, and harvesting urban food trees. This cycle diagram describes some of the activities being undertaken by initiatives focused on each pillar. These pillars act synergistically to support the establishment, maintenance, and utilization of urban food trees

two organizations (Common Ground and LifeCycles) had produced free handbooks on establishing and running community fruit harvesting initiatives.

Of the 37 initiatives we identified, $73 \%$ were founded in 2007 or later. Planting and harvesting were the most common activities, with $51 \%$ of the initiatives engaged in each, versus $32 \%$ for mapping (Table 1). Three initiatives $(8 \%)$ engaged in all three activities, and seven more $(19 \%)$ engaged in two activities, but the majority (73\%) engaged in only one of the three activities, either planting (10 initiatives), mapping (4), or harvesting (13) (Table 1). Several initiatives expressed interest on their websites in expanding their mission to include one or both of the remaining activities.

We suspect that there are many more UFF initiatives in cities around the world that our search did not reveal, either because their websites are not in English, they have no online presence, or our search terms did not capture them.

Urban forestry master plan analysis

Our online search revealed 30 urban forestry master plans, 20 from cities in the United States and 10 from
Canadian cities (Table 2). A total of 2,099 pages of text were analyzed. We found that the majority ( 23 cities, or $77 \%$ ) included no mention of "fruit" or "food" in the context of human consumption, but did include "wildlife," implying that wildlife habitat is generally prioritized over human food security in the context of urban forest planning. Only four (13\%) UFMPs mentioned food in the context of human food security. Three were located in British Columbia (Victoria, Selchelt, and Sannich), and one in California (Nanaimo). Three cities did not make any mention of food, fruit, or wildlife (Table 2).

The potential urban food forestry capacity of Burlington, VT

We calculated the total amount of publicly accessible open space in Burlington to be 180 hectares, which is approximately $4.5 \%$ of the total city area. This meant that trees would be planted on 9,45 , or 90 hectares under our three coverage scenarios, resulting in the production of between 109 and 3,277 edible tons of apples (Table 3). Translating this production into food security needs, we estimated the total annual minimum recommended fruit intake for the entire population of Burlington would be 3,023 metric tons. Five of our nine scenarios met at least a third of this need, with the best-yielding case under the most widely planted scenario surpassing it (Fig. 2).

Further, we estimated that 4,840 individuals, or $11.7 \%$ of the total population of Burlington, would be classified as very food insecure, each with a caloric deficit calculated as 182,500 annually, for a total annual caloric deficit in Burlington of 833 million kilocalories. Planting only $5 \%$ of available open space could meet the caloric deficit of 7-20\% of Burlington's VFI population; larger investments in planting greater areas would provide at least a third of these deficit calories, and in the three highest scenarios, equal to or greater than $100 \%$ (Fig. 2).

Under the $50 \%$ yield scenario, 67.6 ha (37\% of Burlington's open space) would be required to fully meet the caloric deficit of VFI individuals, and 124.8 ha (69\% of Burlington's open space) would be required to provide the minimum daily fruit recommendation for the entire city population. At a planting density of 2,400 trees per hectare, this would mean planting 162,155 and 299,721 trees, respectively, though yields could be increased through multi- 
Table 2 Thirty US and Canadian cities with urban forestry master plans analyzed for the number of times they mention the terms "fruit," "food," or "wildlife". More than three-quarters of cities did not mention urban trees as providing fruit or food, but did mention wildlife

\begin{tabular}{|c|c|c|c|c|c|}
\hline City & $\begin{array}{l}\text { Pages } \\
\text { analyzed }\end{array}$ & $\begin{array}{l}\text { Year of } \\
\text { publication }\end{array}$ & $\begin{array}{l}\text { Instances } \\
\text { of "fruit" }\end{array}$ & $\begin{array}{l}\text { Instances } \\
\text { of “food" }\end{array}$ & $\begin{array}{l}\text { Instances } \\
\text { of "wildlife" }\end{array}$ \\
\hline Saanich, British Columbia & 105 & 2010 & 27 & 62 & 52 \\
\hline Selchelt, British Columbia & 56 & 2010 & 7 & 51 & 27 \\
\hline Nanaimo, CA (draft) & 116 & 2009 & 17 & 16 & 47 \\
\hline Victoria, British Columbia & 63 & 2011 & 9 & 8 & 15 \\
\hline Banff, Alberta & 121 & 2008 & 0 & 0 & 59 \\
\hline Burlington, VT & 64 & 2002 & 0 & 0 & 21 \\
\hline Seattle, WA & 106 & 2007 & 0 & 0 & 17 \\
\hline Lacey, WA & 108 & 2005 & 0 & 0 & 16 \\
\hline Vancouver, British Columbia & 96 & 2007 & 0 & 0 & 16 \\
\hline Chicago, IL & 39 & 2010 & 0 & 0 & 14 \\
\hline St. Catherine's, Ontario & 69 & 2011 & 0 & 0 & 12 \\
\hline Brookings, SD & 89 & 2010 & 0 & 0 & 11 \\
\hline Chesapeake, VA & 34 & 2010 & 0 & 0 & 9 \\
\hline Arlington, VA & 38 & 2004 & 0 & 0 & 8 \\
\hline Charlottesville, VA (draft) & 77 & 2009 & 0 & 0 & 8 \\
\hline Harbord Village, Toronto & 82 & 2007 & 0 & 0 & 8 \\
\hline Burlington, Ontario & 60 & 2010 & 0 & 0 & 7 \\
\hline Calgary, Alberta & 61 & 2007 & 0 & 0 & 5 \\
\hline Louisville, KY & 86 & 2007 & 0 & 0 & 5 \\
\hline San Francisco, CA & 32 & 2006 & 0 & 0 & 5 \\
\hline Wellington, Toronto & 96 & 2009 & 0 & 0 & 5 \\
\hline Syracuse, NY & 56 & 2001 & 0 & 0 & 4 \\
\hline Boone, NC & 80 & 2009 & 0 & 0 & 2 \\
\hline Norman, OK & 34 & 2006 & 0 & 0 & 2 \\
\hline Alexandria, VA & 91 & 2007 & 0 & 0 & 1 \\
\hline Dunn, WI & 34 & 2008 & 0 & 0 & 1 \\
\hline Tigard, OR & 35 & 2009 & 0 & 0 & 1 \\
\hline Austin, TX & 63 & 2009 & 0 & 0 & 0 \\
\hline Grand Rapids, MI & 55 & 2009 & 0 & 0 & 0 \\
\hline Walla-Walla, WA & 53 & 2004 & 0 & 0 & 0 \\
\hline
\end{tabular}

story polyculture plantings (Rivera et al. 2004) and the number of trees could also conceivably be reduced by a factor of 10 or more if slow-maturing fully-sized trees were used (Yuan 2009).

\section{Climate-Food-Species Matrix}

Our analysis of the Climate-Species Matrix by Roloff et al. (2009) revealed 19 species (7\% of the original 250) that are actively bred and cultivated for human consumption. We added an additional 51 species to generate our CFSM (Table 4). Of these 70 species, 22 $(31 \%)$ received an edibility ranking of 5 points, 21 $(30 \%)$ received 4 , and $11(15 \%)$ received 3 points.
Among these 54 species that met at least three of our edibility criteria, we identified $30(43 \%)$ as being the most tolerant to extreme weather (shown in bold in Table 4), as they are both drought tolerant and hardy to at least $-20{ }^{\circ} \mathrm{C}$. We suggest these 30 species are of the greatest general suitability for temperate urban food forestry. Ultimately, the appropriateness of each species will depend on local factors such as site conditions, climate, invasive potential, and social preference.

\section{Discussion}

In our initial investigation into the theoretical and practical role of food trees in urban landscapes, we 
Table 3 Calculations for the yield and edible calories of apples produced in Burlington, Vermont, from nine treeplanting scenarios: a factorial combination of planting coverage area of 5, 25, and $50 \%$ of available open space, and 25, 50, and $75 \%$ of optimal high-density orchard yield. Edible production is expressed in terms of the amount of people in
Burlington who could have their FAO/WHO (2004) daily recommendation of fruit met, and the amount of very food insecure people who could have their deficit calories supplied (see calculations in text). Total yield values have been reduced by $10 \%$ to account for the inedible portion of apples

\begin{tabular}{|c|c|c|c|c|c|c|c|c|c|}
\hline Open space planted & 5 & & & 25 & & & 50 & & \\
\hline Open space planted (ha) & 9.0 & & & 45.1 & & & 90.2 & & \\
\hline Percent of mature yield achieved $(\%)$ & 25 & 50 & 75 & 25 & 50 & 75 & 25 & 50 & 75 \\
\hline Total fruit yield (metric tons/year/ha) & 13.5 & 26.9 & 40.4 & 13.5 & 26.9 & 40.4 & 13.5 & 26.9 & 40.4 \\
\hline Total fruit yield (metric tons/year) & 121 & 243 & 364 & 607 & 1,214 & 1,820 & 1,214 & 2,427 & 3,641 \\
\hline Edible fruit yield (metric tons/year) & 109 & 218 & 328 & 546 & 1,092 & 1,638 & 1,092 & 2,184 & 3,277 \\
\hline Edible fruit calories $\left(\mathrm{kcal} \times 10^{6}\right)$ & 59.0 & 118.0 & 176.9 & 294.9 & 589.8 & 884.7 & 589.8 & 1179.6 & 1769.3 \\
\hline $\begin{array}{l}\text { Minimum daily fruit intake recommendation met } \\
\text { (people) }\end{array}$ & 1,496 & 2,992 & 4,488 & 7,481 & 14,961 & 22,442 & 14,961 & 29,923 & 44,884 \\
\hline Minimum daily fruit intake recommendation met (\%) & 4 & 7 & 11 & 18 & 36 & 54 & 36 & 72 & 108 \\
\hline VFI deficit calories met (people) & 323 & 646 & 969 & 1,616 & 3,232 & 4,847 & 3,232 & 6,463 & 9,695 \\
\hline VFI deficit calories met $(\%)$ & 7 & 13 & 20 & 33 & 67 & 100 & 67 & 134 & 200 \\
\hline
\end{tabular}

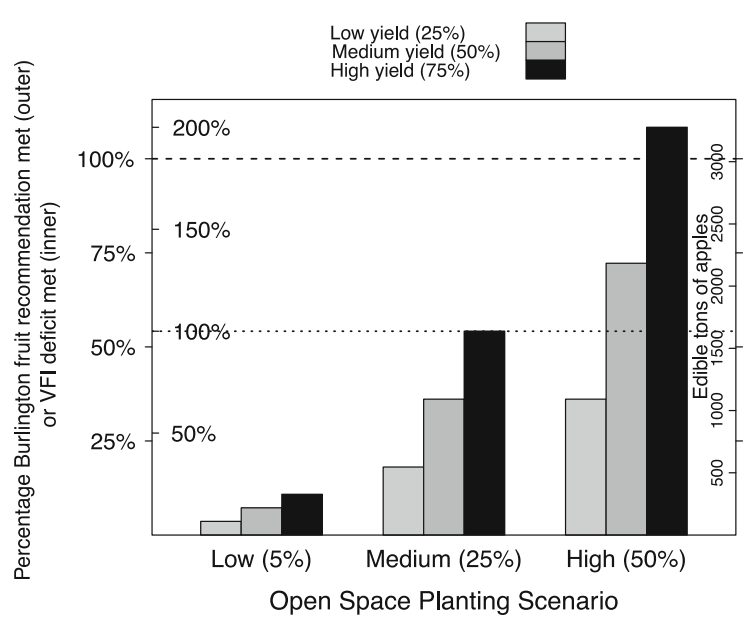

Fig. 2 The number of people in Burlington, VT, who could be supported by the edible calories produced from apples grown on urban food trees under nine planting scenarios: planting coverage area of 5, 25, and $50 \%$ of available open space, and yields per hectare at low, medium, and high levels relative to optimal commercial yield $(25,50$, and $75 \%$ respectively). People supported by UFF production are calculated as percentage of both the number of very food insecure people in Burlington who could have their annual deficit calories supplied by UFF apples (with $100 \%$ shown by the dotted horizontal line), and the total population who could have their minimum daily recommended serving of fruit supplied (with $100 \%$ shown as the dashed horizontal line)

found that grassroots initiatives based around planting, mapping, and/or harvesting urban food trees have been growing rapidly over the past 5 years in North
America, but that to date little work has been done to place these individual initiatives in a unifying theoretical and practical context. We have taken the first step towards doing so by developing a formal definition of, and visual representation for, urban food forestry (Fig. 1). Further, each of the four research approaches we utilized demonstrated great potential for UFF initiatives to be more widely used to enhance ecosystem services and improve access and availability to nutrient-dense foods through edible landscaping. We now consider the implications of UFF for food security.

Food security implications

Formally, food security is comprised of four dimensions: food availability, access, utilization, and stability (FAO 2008). Food systems are considered to be vulnerable when one or more of these components is jeopardized or uncertain (FAO 2011). Hunger is a potential outcome, but not necessarily a consequence of food insecurity, although both are strongly linked to poverty (NRC 2006; Tanumihardjo et al. 2007). Recently established UFF initiatives have demonstrated unique mechanisms for improving each of the four aspects of food security and enhancing the resilience of the food system.

First, UFF increases physical food availability by new plantings of food trees on previously unplanted 


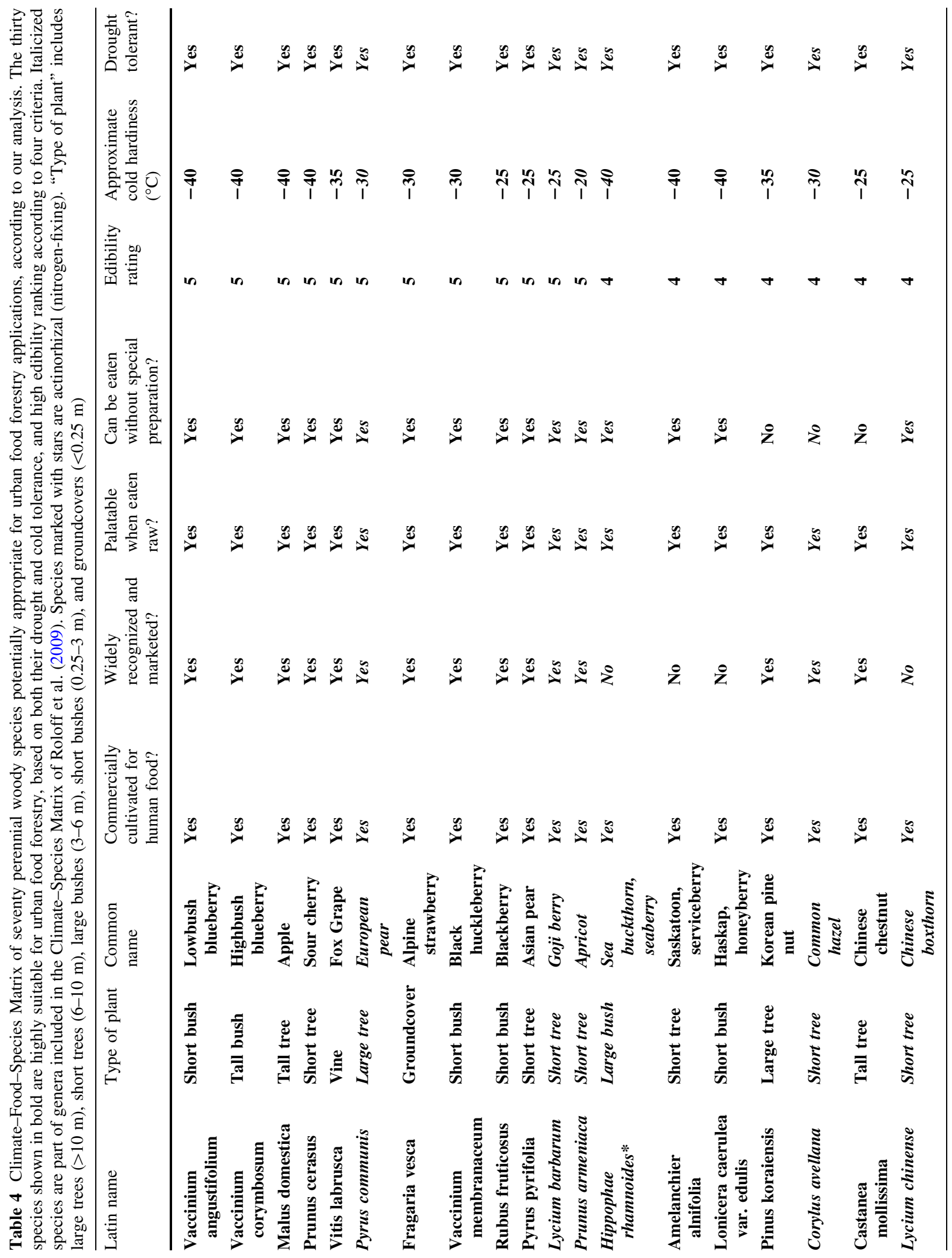




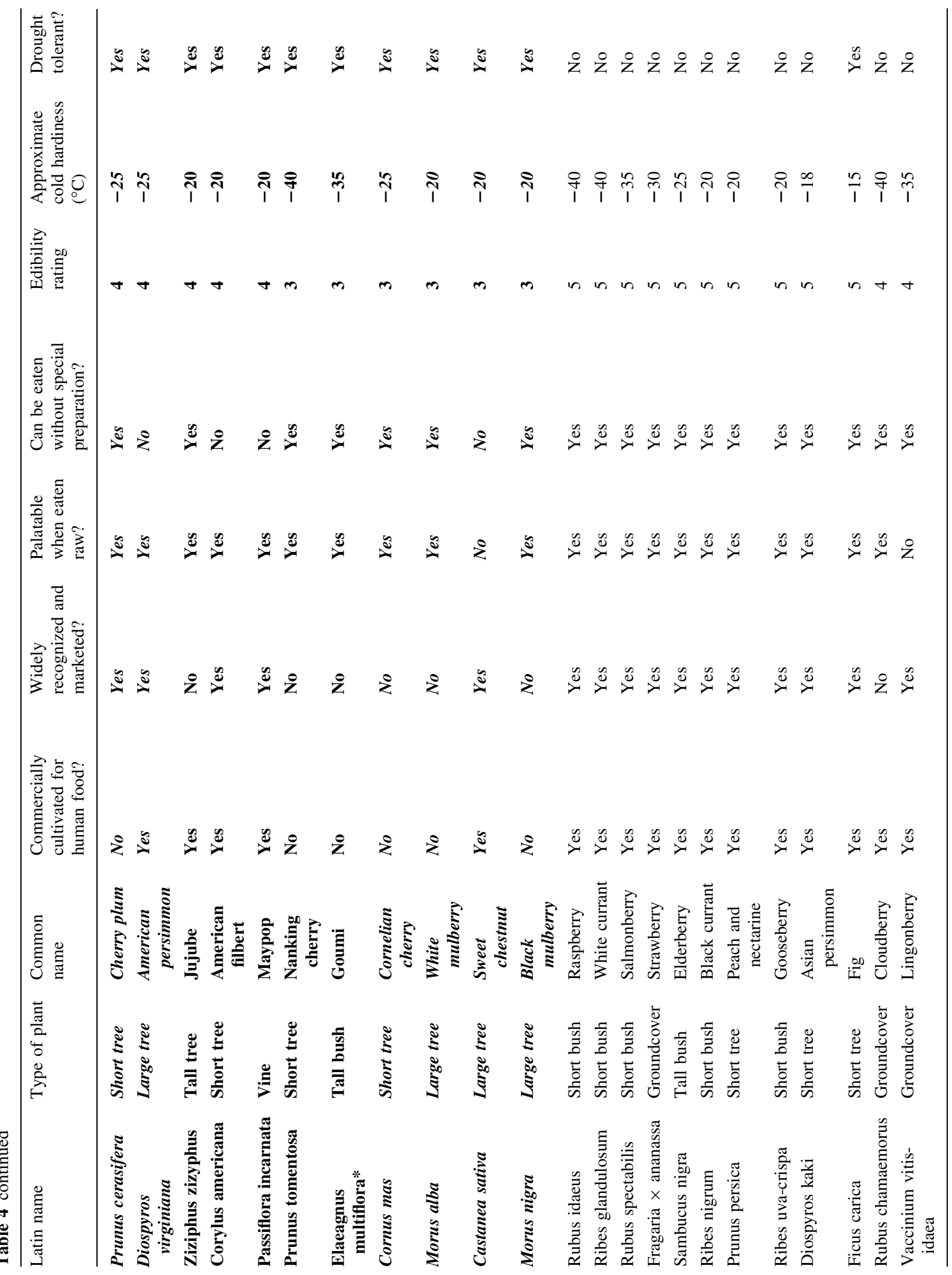




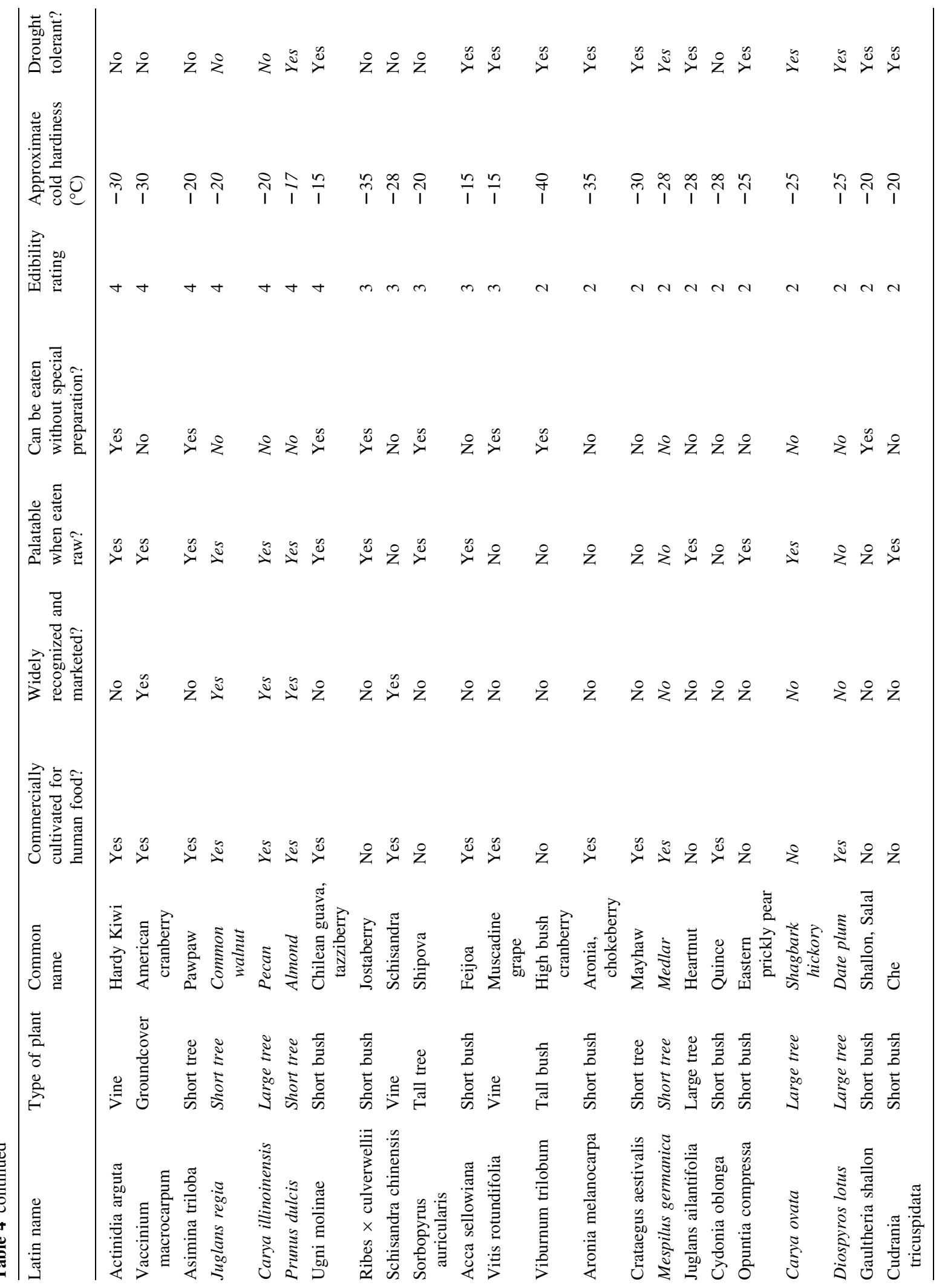




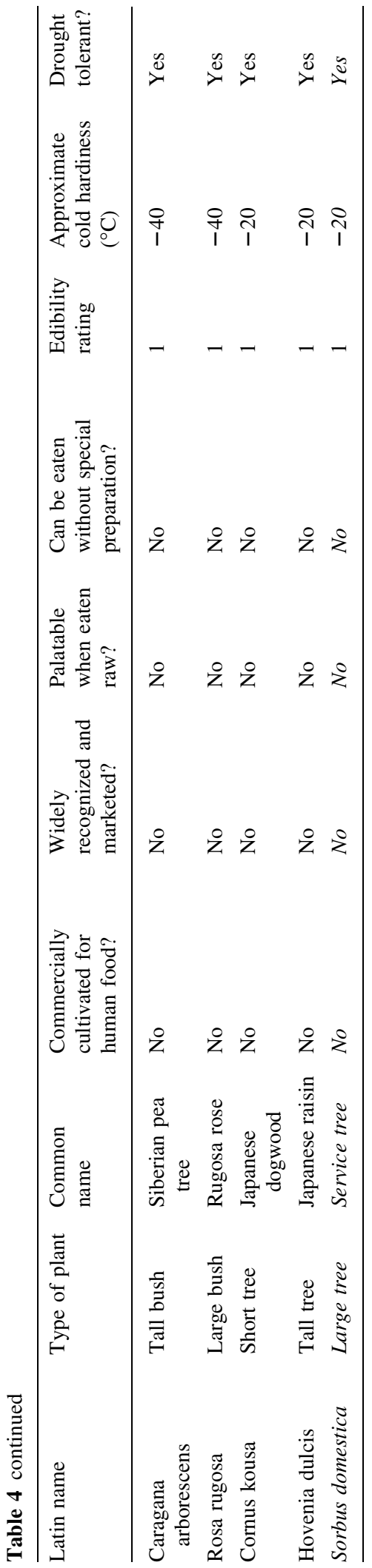

public lands, thus increasing the overall supply of food. Harvesting initiatives that donate unutilized fruit to food banks also add food to the food supply that would otherwise be wasted. Village Harvest in Southern California (http://www.villageharvest.org/), for instance, donated 105,018 kilograms of fruit from backyards and small orchards in 2012 to community food banks and charities.

Second, UFF increases economic and physical access to food by providing free or low-cost food from local sources, often within neighborhood walking distance. Some urban food tree projects also offer participants the opportunity to earn income from the sale of produce. One example of public edible landscaping is the Philadelphia Orchard Project (http://www.phillyorchards.org/), which has planted 32 urban orchards in low-wealth neighborhoods, comprised of 21 species of over 1500 perennial fruit and nut plants.

Third, UFF improves food utilization by providing a free source of nutrient-dense foods that address malnutrition at both ends of the "dual burden" (Doak et al. 2000), by increasing public consumption of nutrient-dense and phytochemical-rich foods to reduce malnutrition and non-communicable diseases, in line with recommendations by major health organizations (e.g., FAO/WHO 2004). For food insecure individuals suffering from either overnutrition or undernutrition, UFF provides free nutrient-dense foods that otherwise may not be affordable due to the inverse relation between the energy density of food $(\mathrm{MJ} / \mathrm{kg})$ and the energy cost $(\$ / \mathrm{MJ})$, which results in energy-dense foods being more accessible than nutrient-dense foods like fruits and vegetables (Drewnowski and Specter 2004). In the context of Burlington, overnutrition is a rapidly growing problem. Approximately $57.7 \%$ of Vermonters are overweight, $23.2 \%$ of whom are obese (CDC 2012). Obesity is estimated to collectively cost the State, its employers, and its citizens between \$618-718 million annually (Jeffords 2010). The Center for Disease Control (CDC) has partly linked low fruit consumption to obesity, where only $38.9 \%$ of Vermont adults consume the recommended amount of fruit (CDC 2012). Strategic UFF initiatives could partly offset these costs. Furthermore, UFF can diversify diets to include nutritious and unusual fruits and nuts that are often neglected in allotment gardens, such as saskatoon, honeyberry, and sea buckthorn, which are in increasingly high demand by the public 
(Jurikova et al. 2012). Recently founded UFF initiatives give urban citizens free access to such fruits, some of which have unique bioactive properties and are otherwise unavailable due to the challenges in producing and transporting them commercially.

Finally, both harvesting and planting initiatives have some capacity to contribute to food stability by buffering shocks to food supplies, particularly in times of economic downturn when donations to food banks decline in conjunction with rising demand. The seasonal availability of fruit can be extended by polycultural edible landscaping that spreads fruit harvest over 7-8 months (Dana 2001), which is also important for urban biodiversity habitat (Colding 2007) and synergistic with urban beekeeping. Additional season extension can be achieved through the use of climate-controlled storage that can preserve certain fruits for 3-11 months (Thompson 2010; Leja et al. 2003), and through preservation via canning, freezing, dehydrating, pickling, pressing, fermenting, or creating value-added products for retail sales. Decentralizing fruit production, which is presently concentrated in one region in the US, where over half of U.S. fruit is produced in California (USDA 2006), would also reduce the dependency of cities on distant sources of food that are susceptible to a variety of potential supply shocks (Fraser et al. 2005).

One major advantage of cultivating food in cities is the abundance of eager volunteer labor and proximity to people, businesses, schools, food banks, supermarkets, hospitals, and other nodes of congregation. This proximity offers opportunities for new business and distribution models that take advantage of growing trends in civic agriculture, local food movements, and agritourism. These transdisciplinary trends include community supported agriculture (CSAs), farmers markets, you-pick orchards, Slow Food restaurants, alternative food stores, and consumer cooperatives. Leveraging these models could provide novel forprofit and charity opportunities for increasing the availability, access, and utilization of nutrient-dense foods at little to no cost to the end-user and aiding with the production, management, transport, storage, and redistribution of produce.

Despite these advantages, urban food forestry has clear limitations in meeting comprehensive food security. While we have demonstrated that strategically planted and harvested urban food trees can improve food security through the mechanisms described above, the scalability of UFF is difficult to ascertain. Also, urban food trees alone cannot provide a balanced diet and should be seen primarily as part of a multifaceted and comprehensive strategy to combat food insecurity, malnutrition, and poverty. Additionally, the value of ecosystem services not related to food provisioning should be considered when evaluating food forestry as a potential urban land use.

\section{Ecological design and urban planning}

Food provisioning and other ecosystem services provided by UFF can be maximized by using agroecological design principles. Specific techniques might include multi-story planting, using nitrogenfixing species to improve soil fertility, heavy mulching, constructing swales and berms to manage irrigation, and using companion planting promote symbiotic polycultures that maximize yield (e.g., Rivera et al. 2004) and minimize pests and pathogens (e.g., Ellis 1998; Bostonian et al. 2004; Pretty 2008). These techniques are used extensively in permaculture design and temperate forest gardening and have been described in detail by Mollison (1979), Jacke and Toensmeier (2005), and Crawford (2010).

The use of woody perennials, in combination with such strategies, may allow UFF to overcome common problems faced in urban agriculture including lack of access to water and land, securing land tenure (Lovell 2010; De Zeeuw et al. 2011), and overcoming low solar radiation, soil and air pollution, soil compaction, shallow effective rooting depth, and frequent water imbalances (drought or excessive wetness) (Blanco and Lal 2010; Erikson-Hamel and Danso 2010; Pearson 2010). There are also opportunities to agriculturally retrofit, or "agrifit," existing green infrastructure, for example by planting shade-tolerant understory species in the urban forest, or grafting non-productive urban fruit trees with high-quality cultivars, a technique that has recently gained press as "guerilla grafting."

Numerous design strategies have been implemented to pilot UFF, though none to date at the planting scale we examined here. Existing design strategies include large-scale multi-hectare patches like the Beacon Food Forest in Seattle, scattered urban orchards in low-income neighborhoods like the Philadelphia Orchard Project, and small solitary features like the Dr. George W. Carver edible park in 
Asheville, NC. The city of Calgary has opted for an adaptive management approach trialing seven fruitand nut-bearing species planted in five configurations: alongside community gardens, in public parks, as regional orchards, along pedestrian routes, and in urban domestic gardens. Evaluating the performance of each configuration will allow city officials to determine which strategy is best suited to meet their goals, which include bolstering local food production, fostering community involvement, and enhancing public education (City of Calgary 2012).

Various ecologically-oriented urban planning strategies that conceptually overlap with UFF have been proposed. In particular, continuous productive urban landscapes (CPULs) (Viljoen 2005), or multifunctional linear landscape features that combine food production, recreation, green space, social space, and aesthetic value, share principles with UFF. Erickson et al. (2011) found that roughly $45 \%$ of residents in Chittenden County (where Burlington is located) are willing to enroll their land in cooperative agricultural land management programs, and propose CPULs as a way to link these residential parcels to the urban core of Burlington. Another closely related concept to CPULs that draws on agroforestry is "ecobelts" (Bentrup et al. 2001; Bentrup and Kellerman 2003). Food-centric urban planning paradigms have also been proposed for overcoming problems associated with urban food production, storage, and distribution, for instance agrarian urbanism, which is a New Urbanist response to addressing limitations of agricultural retention, agricultural urbanism, and urban agriculture (Duany 2011). These concepts could provide UFF with a broader urban planning context, although the greatest current opportunity likely lies in edible landscaping of public spaces.

\section{Species multifunctionality}

The functional advantages of urban food forestry stem primarily from the multifunctionality of food trees themselves (MacDaniels and Lieberman 1979). For example, sea buckthorn (Hippophae rhamnoides), which may range in height from one to several meters, offers the traditional benefits of urban trees (e.g., carbon sequestration and air purification), plus nitrogen fixation, high drought and cold tolerance, and heavy yields of exceptionally nutrient-dense fruits with high commercial value that are being studied for disease prevention (e.g., Christaki 2012).

While beyond the scope of this paper, other traits and functions that might be locally important in species selection include shade and soil tolerance, including tolerance of heavy metals and other pollutants (SamsøePetersen et al. 2002), invasive potential, cultural relevance, nitrogen fixation, nutrient density, market value, and wildlife value. Further research could make use of more extensive plant databases, including those developed by Plants for a Future (http://pfaf.org), Jacke and Toensmeier (2005:495-562), and the USDA Agricultural Research Service (2010). Once species are selected, there may be tradeoffs between cultivars or management tactics that produce different costs and maintenance requirements and affect yields (Jacke and Toensmeier 2005:51). For example, fruit trees pruned to be short and accessible will have a lower carbon sequestration potential than a large tree, and tall trees sacrifice a degree of social engagement due to inaccessible fruit.

\section{Land tradeoffs}

Similarly, tradeoffs are inevitable when embedding food production in regional land use planning. One concern with increasing urbanization is that expanding cities will overtake productive land and push food production further away from population centers, increasing costs of production and transport (Godfray et al. 2010). Growing fruits and nuts within urban centers can help alleviate this problem while aligning with the goals of the USDA, WHO, and FAO to improve fruit production and consumption. Presently in the US, citizens would need to increase fruit consumption by $132 \%$ to meet current recommended intake levels, which would require an additional 1.6 million hectares of land, constituting a $53 \%$ increase of land devoted to fruit production if this requirement were met domestically (USDA 2006). While the scale of planting we proposed here for Burlington is ambitious, considering that cities within the continental U.S. collectively contain an estimated 16 million acres of land cultivated with turf grass (Springer 2012), planting urban food trees on public land could provide a considerable boost to local fruit production, and it is encouraging to see that Burlington has the theoretical capacity to supply the entire recommended fruit needs for its population using available public 
lands. However, urban communities will still need to determine whether UFF offers the highest value versus other possible land uses such as new housing, a soccer field, or a dog park.

\section{Conclusion}

We have presented urban food forestry as an emerging multifunctional and interdisciplinary approach to increasing urban sustainability and resilience, particularly where food security is concerned, and provide a starting point for bridging gaps in knowledge and practice between urban agriculture, urban forestry, and agroforestry. We have shown that urban food forestry can be a valuable strategy to address multiple sustainability challenges (e.g., food security, climate change, and poverty), to contribute to health through affordably increasing public consumption of nutrientdense foods to combat hunger and obesity, and that it can be used to promote sustainable urban development through providing ecosystem services.

While urban food forestry is still in its infancy, food trees are not likely a passing trend in the urban landscape. Thousands of fruit and nut trees have been planted in cities over the past 5 years alone, and there are indications that hundreds of thousands more will be planted over the next decade as the scale, ambition, and policy integration of urban food trees steadily increases. Implementing urban food forestry on a large scale will require significant public-private and transdisciplinary cooperation. Urban planners and other municipal employees, landscape architects, landscape ecologists, and organization representatives and volunteers can play an important role in determining appropriate implementation strategies at the city-wide scale to maximize benefit to urban citizens and target high-risk groups. Input from commercial orchards and nurseries can inform cultivation, storage, and redistribution techniques. Large-scale city fruit production will require adequate planning, staffing, and financing for maintenance, harvesting, storage, processing, and redistribution, most likely accomplished by full-time employees to ensure that the urban food forest is healthy and productive. Case studies of existing grassroots initiatives are important to establish the capacity of urban food forestry in meeting food security, ecosystem services, and other sustainability goals. A systematic evaluation of existing UFF initiatives to produce a synthesis and recommendations on best practices of organizational structure, and test the method we have developed here to estimate UFF yield potential in real-world conditions, would be extremely useful at this stage.

The social, ecological, and economic impact of urban food forestry deserves more attention from the academic community to help UFF reach its maximum potential. Integrating design principles and science from agroecology, agroforestry, orchard science, and plant breeding into urban forestry presents one promising approach to improving urban landscape performance. Further informing this design with research from nutrition and health science, as well as food security experts, could result in planning strategies that systematically target malnutrition and food security on a large scale. In these early stages, there is a need for both qualitative and quantitative research in the form of case studies, and the application of ecological economics and ecosystem service modeling tools to quantify the value of edible landscape features. This information, in concert with advancing design principles and management strategies, would help paint a clearer picture of the costs and benefits associated with UFF and identify strategies for its improvement. Our hope is that the insights from this paper will promote such research and debate, and offer one of many possible multifunctional strategies for solving urban sustainability challenges.

Open Access This article is distributed under the terms of the Creative Commons Attribution License which permits any use, distribution, and reproduction in any medium, provided the original author(s) and the source are credited.

\section{References}

Ahern J (2011) From fail-safe to safe-to-fail: sustainability and resilience in the new urban world. Landscape Ecol 100(4):341-343

Altieri MA, Companioni N, Cañizares K, Murphy C, Rosset P, Bourque M, Nicholls CI (1999) The greening of the "barrios": urban agriculture for food security in Cuba. Agric Hum Values 16:131-140

Belsky JM (1993) Household food security, farm trees, and agroforestry: a comparative study in Indonesia and the Philippines. Hum Organ 52(2):130-141

Bentrup G and Kellerman T (2003) Agroforestry and GIS: achieving land productivity and environmental protection. In: Proc. of the 8th North American Agroforestry Conference. 23-25 June 2003. Corvallis, OR, pp 15-25 
Bentrup G, Schoeneberger M, Josiah S, Francis C (2001) Ecobelts: reconnecting agriculture and communities-case studies. In: Steward WC, Lisec A (eds) Proceedings of the Ecospheres Conference. University of Nebraska, Lincoln, NE, pp 10-12

Bhatt V, Farah LM (2009) Designing edible landscapes. Open House Int 34:5-7

Blanco H , Lal R (2010) Principles of Soil Conservation and Management, pp 261-263

Bostonian NJ, Goulet H, O'Hara J, Masner L, Racette G (2004) Towards insecticide free orchards: flowering plants to attract beneficial arthropods. Biocontrol Sci Technol 14(1):25-37

Boyer J, Liu RH (2004) Apple phytochemicals and their health benefits. Nutr J 3:5

Bradshaw TL, Berkett LP, Kingsley-Richards SL, Griffith MC (2012) Planting organicA orchard 4: a high-density planting with scab-resistant cultivars. (Online) http://www.uvm. edu/ organica/OrganicOrchardInformation/Horticulture/ PlantingOrchard4.html. Accessed Dec 2012

Breust J, Niemelä J, Snep RPH (2008) Applying landscape ecological principles in urban environments. Landscape Ecol 23:1139-1142

Brown KH, Jameton AL (2000) Public health implications of urban agriculture. J Public Health Policy 21(1):20-39

Camhis M (2006) Sustainable Development and Urbanization. In: Marco K (ed) The Future of Sustainability. Springer, Netherlands, pp 69-98

CDC (2012) Center for Disease Control. Vermont state nutrition, physical activity, and obesity profile. (Online) http://www. cdc.gov/obesity/stateprograms/fundedstates/pdf/VermontState-Profile.pdf. Accessed Dec 2012

Christaki E (2012) Hippophae rhamnoides L. (Sea Buckthorn): a potential source of nutraceuticals. Food and Public Health 2(3):69-72

City of Calgary (2012) Community orchards (Online) http:// www.calgary.ca/CSPS/Parks/Pages/Programs/Communityorchards.aspx. Accessed Mar 2012

Clark WC (2007) Sustainability science: a room of its own. Proc Natl Acad Sci 104(6):1737-1738

Cluff M, Jones W (2011) Summary-OECD-FAO Agricultural Outlook 2011-2020. (Online) http://www.agri-outlook.org. Accessed Feb 2012

Colding J (2007) Ecological land-use complementation for building resilience in urban ecosystems. Lands Urb Plan 81:46-55

Crawford M (2010) Creating a forest garden: working with nature to grow edible crops. Green Books, UK

Dana MN (2001) Fruits and nuts for edible landscaping. Purdue University Cooperative Extension Service. Landscape Horticulture Publication HO-190-W

Darmon N, Darmon M, Maillot M, Drewnowski A (2005) A nutrient density standard for vegetables and fruits: nutrients per calorie and nutrients per unit cost. J Am Dietetic Assoc 105(12):1881-1884

De Groot RS, Alkemade R, Braat L, Hein L, Willeman L (2009) Challenges in integrating the concept of ecosystem services and values in landscape planning, management and decision making. Ecol Complex 7:260-272

De Zeeuw H, Van Veenhuizen R, Dubbeling M (2011) The role of urban agriculture in building resilient cities in developing countries. J Agric Sci 149:153-163
Drewnowski A, Specter SE (2004) Poverty and obesity: the role of energy density and energy costs. Am J Clin Nutr 79:6-16

Duany A (2011) Garden cities: theory and practice of agrarian urbanism. The Prince's Foundation for Building Community, London

Dubbeling M, Campbell MC, Hoekstra F, van Veenhuizen R (2009) Building resilient cities. Urb Agric Mag 22:3-11

Easterling WE (2007) Climate change and the adequacy of food and timber in the 21st century. Proc Natl Acad Sci 104(50): 19679

Ellis MA (1998) Effects of an apple scab-resistant cultivar on use patterns of inorganic and organic fungicides and economics of disease control. Plant Dis 82(4):428-433

Erickson DL, Lovell ST, Méndez VE (2011) Landowner willingness to embed production agriculture options in residential areas of Chittenden County, VT. Landsc Urb Plan 103:174-184

Erickson-Hamel N, Danso G (2010) Agronomic considerations for urban agriculture in southern cities. Int J Agric Sustainability 8:86-93

FAO (2008) Climate change and food security: a framework document. Food and Agriculture Organization of the United Nations: Rome. (Online) http://www.fao.org/forestry/ 15538-079b31d45081fe9c3dbc6ff34de4807e4.pdf. Accessed Dec 2012

FAO (2010) Country profile: Food security indicators. United States of America (Online) http://www.fao.org/fileadmin/ templates/ess/documents/food_security_statistics/country_ profiles/eng/USA_E.pdf. Accessed Mar 2012

FAO (2011) Food, agriculture and cities: Challenges of food and nutrition security, agriculture and ecosystem management in an urbanizing world. (Online) http://www.fao.org/file admin/templates/FCIT/PDF/FoodAgriCities_Oct2011.pdf. Accessed Mar 2012

FAO/WB (2008) Urban agriculture for sustainable poverty alleviation and food security. Food and Agriculture Organization of the United Nations: Rome. (Online) http://www. fao.org/fileadmin/templates/FCIT/PDF/UPA_-WBpaperFinal_October_2008.pdf. Accessed Dec 2012

FAO/WHO (2004) Fruit and vegetables for health. Report of a joint FAO/WHO workshop. 1-3 Sept 2004, Kobe, Japan

Fraser EDG, Mabee W, Figge F (2005) A framework for assessing the vulnerability of food systems to future shocks. Futures 37(6):465-479

Garrity DP (2004) Agroforestry and the achievement of the Millennium Development Goals. Agrofor Syst 61:5-17

Gerhauser C (2008) Cancer chemopreventitive potentials of apples, apple juice, and apple components. Planta Med 74:1608-1624

Godfray HCJ, Beddington JR, Crute IR, Haddad L, Lawrence D, Muir JF, Pretty J, Robinson S, Thomas SM, Toulmin C (2010) Food security: The challenge of feeding 9 billion people. Science 327:812-818

Grimm NB, Faeth SH, Golubiewski NE, Redman CL, Wu J, Bai X, Briggs JM (2008) Global change and the ecology of cities. Science 319:756-760

Jacke D, Toensmeier E (2005) Edible forest gardens: ecological design and practice for temperate climate permaculture, vol 2. Chelsea Green Publishing Company, Vermont

Jeffords JM (2010) Vermont legislative research service: The overall costs of obesity. (Online) http://www.uvm. 
edu/ vlrs/Health/Overall\%20costs\%20of\%20obesity.pdf. Accessed Dec 2012

Jurikova T, Sochor J, Rop O, Mlček J, Balla S, Szekeres L, Žitný R, Zitka O, Adam V, Kizek R (2012) Evalution of polyphenolic profiles and nutritional value of non-traditional fruit species in the Czech Republic-a comparative study. Molecules 17:8968-8981

Kates RW, Clark C, Corell R, Hall JM, Jaeger CC, Lowe I, McCarthy JJ et al (2001) Sustainability science. Science 292:641-642

Konijnendijk CC (2003) A decade of urban forestry in Europe. For Policy and Econo 5(2):173-186

Konijnendijk C, Gauthier M (2006) Urban forestry for multifunctional land use. In: van Veenhuizen R (ed) Cities farming for the future: urban agriculture for green and productive cities. International Development Research Centre, Ottawa. (Online) http://www.idrc.ca/en/ev-103884-201-1-DO TOPIC. html. Accessed Dec 2012

Kumar BM (2006) Agroforestry: the new old paradigm for Asian food security. J Tropical Agric 44:1-14

Lal R (2012) Urban ecosystems and climate change. In: Lal R, Augustin B (eds) Carbon sequestration in urban ecosystems. Springer Science, pp 3-19

Lassoie JP, Buck LE (2000) Development of agroforestry as an integrated land use management strategy. In: Garrett HE, Rietveld WJ, Fisher RF (eds) North American agroforestry: an integrated science and practice. American Society of Agronomy, Madison, pp 1-29

Leja M, Mareczek A, Ben J (2003) Antioxidant properties of two apple cultivars during long-term storage. Food Chemistry 80:303-307

Lelle MA, Gold MA (1994) Agroforestry systems for temperate climates: Lessons from Roman Italy. Forest and Conserv Hist 38(3):118-126

Lovell ST (2010) Multifunctional urban agriculture for sustainable land use planning in the United States. Sustainability 2:2499-2522

Lovell ST, Johnston DM (2009) Designing landscapes for performance based on emerging principles in landscape ecology. Ecol Soc 14(1):44

Lundy L, Wade R (2011) Integrating sciences to sustain urban ecosystem services. Prog Phys Geogr 35(5):653-669

MacDaniels LH, Lieberman AS (1979) Tree crops: a neglected source of food and forage from marginal lands. BioScience 29(3): 173-175

Maco SE, McPherson EG (2003) A practical approach to assessing structure, function, and value of street tree populations in small communities. J Arboric 29(2):84-97

McManus PS, Heimann MF (1997) Apple and pear disorder: Sooty blotch and flyspeck. University of WisconsinExtension, Cooperative Extension, Publication A3173

Mollison B (1979) Permaculture: a designer's manual. Tagari Publications

Musacchio LR (2011) The grand challenge to operationalize landscape sustainability and the design-in-science paradigm. Landscape Ecol 26:1-5

Nair PKR (1993) An introduction to agroforestry. Kluwer Academic Publishers, The Netherlands

Nair PKR (2007) The coming age of agroforestry. J Sci Food Agric 87:1613-1619
Nassaur JI, Opdam P (2008) Design in science: extending the landscape ecology paradigm. Landscape Ecol 23:633-644

National Research Council NRC (2006) Food insecurity and hunger in the United States: an assessment of the measure. Wunderlich GS, Norwood JL (eds) National Academic Press Washington, DC

Nordahl D (2009) Public produce: The new urban agriculture. Island Press

Northern New York Agricultural Development Program (NNYADP) (2010) Final report of work completed April 1, 2008 to December 1, 2009. New York College of Agriculture and Life Sciences, Cornell University, Ithaca, New York

North Carolina Cooperative Extension Service (NCCE) (2008) High density apple orchard management. (Online) http:// www.ces.ncsu.edu/depts/hort/hil/pdf/ag-581.pdf. Accessed Dec 2011

Nowak DJ (2006) Institutionalizing urban forestry as a "biotechnology" to improve environmental quality. Urb For Urb Green 5:93-100

Nowak DJ, Dwyer JF (2007) Benefits and costs of urban forest ecosystems. In: Kuser JE (ed) Urban and community forestry in the Northeast. Springer, Netherlands, pp 25-46

O'Farrell PJ, Anderson PML (2010) Sustainable multifunctional landscapes: a review to implementation. Curr Opin Environ Sustain 2:59-65

Olson RK, Schoeneberger MM, Aschmann SG (2000) An ecological foundation for temperate agroforestry. In: Garrett HE, Rietveld WJ, Fisher RF (eds) North American agroforestry: an integrated science and practice. American Society of Agronomy, Madison, pp 31-61

Pearson CJ (2010) Guest editorial: challenging, multidimensional agriculture in cities. Int J Agric Sustain 8:3-4

Pijanowski BC, Iverson LR, Drew CA, Bulley HNN, Rhemtulla JM, Wimberly MC, Bartsch A, Peng J (2010) Addressing the interplay of poverty and the ecology of landscapes: a grand challenge topic for landscape ecologists? Landscape Ecol 25:5-16

Plants for a Future (PFAF) (2010) (Online) http://www.pfaf.org. Accessed Jan 2012

Potschin M, Haines-Young R (2006) "Rio+10", sustainability science and landscape ecology. Landsc Urb Plan 75:62-174

Pretty J (2008) Agricultural sustainability: concepts, principles and evidence. Philosoph Trans Royal Soc, Bot Sci 363 (1491):447-465

Purdue University New Crop Resource Online Program (PUNCR) (2011) (Online) http://www.hort.purdue.edu/ newcrop/. Accessed Jan 2012

Rees WE (1992) Ecological footprints and appropriated carrying capacity: what urban economics leaves out. Environ Urb 4(2):121-130

Rees WE, Wackernagel M (1996) Urban ecological footprints: why cities cannot be sustainable — and why they are a key to sustainability. Environ Impact Assess Rev 16:223-248

Reganold JP, Glover JD, Andrews PK, Hinman HR (2001) Sustainability of three apple production systems. Nature 410:926-930

Rivera MA, Quigley MF, Scheerens JC (2004) Performance of component species in three apple-berry polyculture systems. HortScience 39(7):1601-1606 
Robinson TL (2005) Should New York apple growers move up to higher tree densities? (Part 1). N Y Fruit Q 13(1):27-31

Robinson T (2011) Advances in apple culture worldwide. Revisa Brasileira de Fruticultura 33:37-47

Robinson T, Hoying SA, DeMaree A, Iungerman K, Fargione M (2007) The evolution towards more competitive apple orchard systems in New York. N Y Fruit Q 15(1):3-9

Roloff A, Korn S, Gillner S (2009) The Climate-Species Matrix to select tree species for urban habitats considering climate change. Urb For Urb Green 8:295-308

Rowntree RA (1998) Urban forest ecology: conceptual points of departure. J Arboric 24(2):62-70

Sachez PA (1995) Science in Agroforestry. Agrofor Syst 30: $5-55$

Samsøe-Petersen L, Larsen EH, Larsen PB, Brun P (2002) Uptake of trace elements and PAHs by fruit and vegetable from contaminated soils. Environ Sci Technol 36:30573063

Schmidhuber J and Shetty P (2003) The nutrition transition to 2030: why developing countries are likely to bear the major burden. http://www.fao.org/fileadmin/templates/esa/Global_ persepctives/Long_term_papers/JSPStransition.pdf. Accessed Dec 2012

Schmidhuber J, Tubiello FN (2007) Global food security under climate change. Proc Natl Acad Sci 104(50):19703-19708

Smith JR (1929) Tree crops: a permanent agriculture. Quinn and Boden Company, Inc., Rahway

Springer TL (2012) Biomass yield from an urban landscape. Biomass and Bioenergy 37:82-87

Stewart H, Hyman J, Buzby JC, Frazao E, Carson A (2011) How much do fruits and vegetables cost? USDA Economic Research Service: Economic Information Bulletin 71

Tanumihardjo SA, Anderson C, Kaufer-Horowitz M, Bode L, Emenaker NJ, Haqq AM, Satia JA, Silver HJ, Stadler DD (2007) Poverty, obesity, and malnutrition: an international perspective recognizing the paradox. J Am Dietetic Assoc 107(11):1966-1972

Termorshuizen JW, Opdam P (2009) Landscape services as a bridge between ecology and sustainable development. Landscape Ecol 24(8):1037-1052

Thompson AK (2010) Controlled atmosphere storage of fruits and vegetables, 2nd edn. CAB International, Cambridge, pp 2-3
United Nations (2004) World urbanization prospects: the 2003 revision. United Nations, New York

United States Census Bureau (2011) State and County QuickFacts: Burlington, Vermont. (Online) http://quickfacts. census.gov/qfd/states/50/5010675.html. Accessed Feb 2012

United States Department of Agriculture (USDA) (2006) Possible implications for US agriculture from adoption of select dietary guidelines, Document ERR-31. Economic Research Service (Online) http://www.ers.usda.gov/ publications/err31/err31c.pdf. Accessed Jan 2012

United States Department of Agriculture (USDA) (2009) Household community fact sheet: Apples. (Online) http:// www.fns.usda.gov/fdd/facts/hhpfacts/New_HHPFacts/ Fruits/HHFS_APPLES_FRESH_F510-515_Final.pdf. Accessed Jan 2012

United States Department of Agriculture (USDA) (2011) Household food security in the United States in 2010. Economic Research Service: Economic Research Report Number 125

United States Department of Agriculture, Agricultural Research Service (USDA ARS) (2010) Germplasm Resources Information Network (Online) http://www.ars-grin.gov/. Accessed Feb 2012

van Leeuwen E, Nijkamp P, Vaz TD (2010) The multifunctional use of urban green space. Int J Agric Sustain 8:20-25

Viljoen A (ed) (2005) Continuous productive urban landscapes: designing urban agriculture for sustainable cities. Architectural Press, Oxford

Weber MS (2000) Optimizing tree density in apple orchards. The Compact Fruit Tree 33(4):119-122

Wu J (2006) Landscape ecology, cross-disciplinarity, and sustainability science. Landscape Ecol 21:1-4

Wu J (2008) Making the case for landscape ecology: an effective approach for urban sustainability. Landscape Ecol 27: 41-50

Wu J (2010) Urban sustainability: an inevitable goal of landscape research. Landscape Ecol 25:1-4

Yuan R (2009) Tree Fruit in the Home Garden. Virginia Polytechnic Institute and State University Cooperative Extension Publication 426-841

Zezza A, Tasciotti L (2010) Urban agriculture, poverty, and food security: Empirical evidence from a sample of developing countries. Food Policy 35:265-273 